\title{
DECENTRALIZATION OF EDUCATION PLANNING AND ITS IMPACT IN QUALITY
}

\author{
Bhawani Prasad Mainali
}

Department of Education, TU, Thakur Ram Multiple Campus, Birganj, Nepal

email: bhawanimainali@gmail.com

\begin{abstract}
this article has attempted to present an overview of basic concept, rationale and trends of decentralization in education planning and to identity the major policy issues and challenges relating to educational quality in Nepalese context. Decentralization in education around the world has based on the assumption that the quality of education will improve by shifting a decision making and accountability closer to schools, class rooms and learners.
\end{abstract}

\section{Keywords}

Decentralization; Deconcentration; Delegation; Devolution; Privatization

\section{Introduction}

Decentralization is considered as critical strategy in many countries for implementing Major reform programmers aimed at reducing poverty, inequality and empowering communities and civil society institutions. Decentralization as a development strategy, it is argued, facilitates people participation and partnerships, and therefore, is an enabling condition for good governance. And good governance is found to be closely linked to social and economic development.

Decentralization is at the top of the reform agenda in many countries. Governments and agencies consider it an indispensable step in efforts to provide quality education for all. However, little is known about its actual implementation and impact on local offices and schools. (UNESCO, 2004). More and more governments see decentralization is a way forward, as a desirable policy. On the other hand the implementation of that policy has mostly failed to live up to expectations (cited from cohen and Peterson, 1999).

With globalization comes increased localization. Decentralizaing educational planning is one major issue which has profoundly transformed planning practice. Most countries have embarked on some kind of decentralization. The process has 
taken different forms in different countries. Decentralization has often been suddenly introduced in developing countries as part of an overall public management reform. However, depending on the context and the support given by central government, it can lead either to the improvement of education or to increased inequalities, even to the spread of corruption. This raises the issue of mechanisms of accountability (UNESOC, 2003:3). Developing countries provide some evidence that decentralization can strengthen local government units financial and legally. However, it is important to recognize that increased discretionary authority often comes alongside a decrease in funding from the central government. Decentralization may pose a challenge to equity, since poor communities may be poorly positioned to take advantage of new financial and planning autonomous, and simultaneously least able to meet the increased burdens on local financial and human resources.

The basic function of democratic decentralization is to ensure that the development planning is more responsive and adaptable to regional and local needs of the population. It ensures people's participation. The national policy on education emphasized the importance of the decentralization of planning and management of education at all levels by ensuring greater community participation (Aggarwas-2008).

The big decisions about education are made by cabinets but they are implemented in classrooms. National decisions are needed to ensure equity and local decisions are needed to tailor them to meet the needs of each community and each child. In recent times there has been a broad movement internationally towards decentralization, transferring authority to local decision makers. Among the arguments in favor is that national policies are one size that do not fit all. General policies must be adopted to be relevant. Each community is different, each school has its character. Too much centralization stifles inventiveness, too much inspection Suppresses initiative (UNESCO, 2004:2-3).

But decentralization is not one thing alone authority can be transferred to local political bodies, to schools, to teachers, to parents. And decentralization is not a panacea, it is a solution to a problem that itself generates problems, such as reduced accountability. Different local policies can produce inequalities in outcomes of studies and futures for children. What is locally adapted can be globally dysfunctional. Hence the question is not: should we deentralizelise? It is rather: What should be decentralized and to whom, when, how, with what means, and with what checks and balance?

Good schooling for pupil of tomorrow is no easy task. The decentralization efforts of recent years would suggest that this approach is becoming a natural framework for the management of education systems. Though this framework a new balance and distribution of roles between the centre and the periphery is emerging (Dalin, 1998). Decentralization in education, some of the planning and most of the action of school improvement takes palace at the school and community levels. Planning sustaining changes in classrooms and schools depends on the ability of head teachers to develop collaborative relations with the community; monitor school quality and efficiency, generating, understanding and use information on interventions in progress; and respond to the emergence of new priorities. For effective planning, opportunities may be needed for generating local financial resources and local control over use of such resource.

Decentralization is the tendency to disperse decision making authority is an organized structure. It ia a fundamental aspect of delegation, to the extent that the authority is not delegated, it is centralized (Weihrich and koonts, 1994). In centralized education system, educational decision making is monopolized by bureaucratic elite anxious to exclude the 
masses from strategic decision and from day to day planning and administration.

Decentralization greatly involves the granting of some of the national government's authority to lower level units, and typically opens the way for the establishment or development of local institutions that are, to a degree, autonomous from central government. Local authorities are generally given expanded rights to develop and allocate local resources, coupled with new responsibilities for bearing program cost (ADB, 2001). A decentralized education system is characterized by the exercise of substaintial power at the local level on many aspects school level education, subject to some limited control by the central government. Responsibility may be decentralized to a region, a province, a district, a town or an individual school or a group of schools (Florestal \& Cooper, 1997). To varying degrees, all developing countries have adopted elements of decentralization in their education systems. Along with the devolution of authority and responsibility for schools from central to local levels. In terms of functions that have been decentralized the curriculum and testing remain centralized practically everywhere. On the other hand functions such as the selection of teachers, text books and other instructional materials and facility construction and maintenance are being left increasingly to schools levels.

\section{Basic concept and images of decentralization}

All the major activities of education can be carried out on either a centralized or a decentralized basis. Decentralization is the creation of autonomous authority, covering relatively small geographical administrative or population units, to carryout of the function hitherto discharged by a central authority. Delegation of authority is not the same as decentralization. Decentralization is a legal arrangement and does not depend on the wish of the superior authority. An authority is free to function within framework of legal provision. Such system facilitates the authorities to plan and implement educational plan \& management to meet the local needs and reduce delays that occurs due to administrative hierarchy (Pradhan, 1998). Decentralization in education is perceived as transfer of decision making power \& authority for planning, management, and use for resources from higher levels of the government to periphery or lower levels, such as, provinces (federal states), districts, urban and rural local bodies, schools and related grassroots level organizations. In fact, decentralization can be defined as a process of sharing power, authority and accountability that facilitates sustainable change. The concept of decentralization as the transfer of responsibility for planning, management, resources raising and allocation from central government and its agencies to: field units of central government or school level; subordinate units; area wide, regional or functional authority; or non governmental private voluntary organization (UNESCO, 1999).

Decentralization about shift in the location of those who govern, about transfer of authority from those in one location or level vis-à-vis education organizations, to those in another level. Decentralization is often defined in terms of four degrees of transfer of authority: deconcentration, delegation, devolution and privatization (Welsh and MCGinn, 1999).

The term decentralization implies dispersal of something aggregated or concentrated around a single point. A common metaphor used to describe this dispersal is that of the pyramid. Most public \& private organizations rely on leaders or specially designated persons, to make decisions for the rest of the members of the organizations. In the both public \& private sector, large organizations tend to be hierarchical in structure, that is to havemultiple layers of authority. Decision made at the top layer affect more people, and those made at the bottom affect fewer people. Decentralization moves authority downward from the point of the pyramid towards the base. 


\section{Forms / Types of decentralization}

Several different ways of classifying decades decentralization have been promoted over the past few decades by those making a clear distinction between centralization and decentralization. The major forms of decentralization can be identified in the literature are:

Delegation: Delegation of authority refers to transferring the authority from higher level to lower level for some specific period or task wished by the superior to function on behalf of him, or to temporary transfer of power and authority to local level for specific time period and in certain specific areas.

Deconcentration: is the handing over of some amount of administrative authority or responsibility to lower levels with in central government ministries or agencies. From a legal standpoint the key feature of deconcentration is that the people given additional responsibility are part of the central ministry, and they continue to act under the supervision of that minis try. It means deconcentration demarcates and assigns some responsibilities of planning and management to local level units without transferring and power and authority, and thus it is an administrative convenience to exercise central control.

Devolution: Devolution of power \& authority is the essence of decentralization. In devolution, powers are transferred to provincial \& local level bodies by law, and the central government relinquishes the decision making role. Devolution of political, administrative and financial powers is essential for effective decentralization.

Devolution has four key features: The body that exercises responsibility is legally separate from the central ministry; the body acts on its own, not under the hierarchical supervision of the central ministry; the body can exercise only the powers given to it by law; and the body can act only within the geographic limits set out in the law. Also, such bodies are often supervised by a board of officials elected by the local population, because the local body is legally separate from the ministry, it can enter into contracts \& conduct other transactions in its own name. The local body is fully responsible for its acts; the central ministry has no responsibility unless the law specifies other arrangements. Although the local body is not under the control of the ministry, it is nevertheless not entirely free to do as it pleases. Local government, must act within the limits set for them by law (florestal \& cooper 1997).

Privatization: privatization which is sometimes referred to as public private partnership (PPP) or market decentralization; is a sub type of delegation. It occurs when a government divests itself of responsibility for carrying out a given public sector task or providing a given service. Arguments in support of privatizing government tasks are that non public sector firms can provide goods \& services more efficiently, effectively and accountably because they are not hampered by bureaucratic politics \& practices or burdened by complex administrative procedures relating to budgeting, disbursing, accounting \& auditing. As a result, they are thought to be better capable of meeting targets \& schedules. Finally, because under such arrangements users are charged for the contracted goods \& services, such firms are under pressure to meet the requirements of users. Some distinguish 'deregulation' as a type of privatization. Deregulation is the removal of legal controls restricting private production or provision of goods \& services formally held under a monopoly by the government or its delegate. By deregulating a government makes it possible of private firms \& NGOs to serve the public, thereby helping to relieve the government of some financial \& administrative burdens, reduce the size and presence of the public sector in the economy, and, hopefully, produce \& provide better quality goods \& services to the public (Cohen \& Peterson, 1999). Theoretically, 
decentralization of power \& authority is a continuum. In practice, however, the degree of devolution of powers depends largely on the specific context in which decentralization strategy is being implemented.

\section{Rationale of decentralization of educational planning}

The importance of decentralization as a development strategy is now widely appreciated. Decentralized planning in education refers to a process where the lower recognized units of planning and management have the authority to set their own targets, identity local specific issues and problems, evolve effective intervention strategies and have the power to allocated resources between various functions of the education sector.

In many developing countries, decision making authority and overall responsibility for planning and management of education system are increasingly being devolved to provincial and district levels. Despite certain advantages of decentralization such as increase local ownership of and accountability for education. Education quality apparently may refers to inputs; processes; outputs; and outcomes (ADB, 2001). In centralized education system decision making is monopolized by bureaucratic elite anxious to exclude the masses from strategic decisions and day to day planning. Decentralization may have an important impact on schooling and other human resources investments. It has been argued that devolution of decision making to local and schools levels and greater market orientation make schools and teachers more accountable to children and parents more sensitive to input costs and more efficient thereby increasing their effectiveness.

Decentralization is one of the most important phenomena to have affected educational planning Reasons of decentralization are numerous. In some cases it is a question of increasing efficiency in management and governance where the state bureaucracy appears heavy and slow, where it has proven unable to tackle issues of teachers development, teacher payment, purchase and distribution of equipments and materials or maintenance of buildings, decentralization appears to be the solution: it can allow a faster identification of problem and the search for more appropriate response. In many cases decentralization also the result of the process of political decentralization, People want to be consulted and involved in decision making that concerns them directly. Decentralization also helps in clarifying lines of accountability (Welsh \& MCGinn, 1999). Similarly several other reasons are behind administrative and planning reform move, including the desire of certain governments to reduce the power of teachers union. But in several developing countries the prime motor of decentralization may have been the search for new resources. Central governments develop the management of the schools that they can no longer finance. Decentralization allows for the mobilization of resources at the local level, through special taxes or community participation that would not be available other wise.

On the basis of decentralized education system, the purpose of the school sector reform plan is to improve efficiency in education, aiming at EFA and MDG goals to reach parity in gender and inclusion, and ensure equitable access to quality education through a holistic school sector approach. It has made attempts to adopt a forward looking approach to respond to regional and global trends and practices making school education relevant to and compatible with people life and liveli hood (MOE, 2009).

In decentralized schools, parents and communities are showing great commitment to their children's schooling. Many contribute strongly to the cost of schooling, by paying several fees and providing practical support. For the reform movement that the decentralization as one of its key element. One of the key motivations here is to create 
ownership with parents, Pupils, teachers and head teacher a lot of more influence over school improvement.

Thesedays, manycountriesaremoving towards decentralization system of education due to the reasons: The magnitude of educational enterprises, the heterogeneity of the clientele for education, the complexity of education system, problem of communication, public expectations from education, financial burden on the central government and the recognition of education as a component of regional development planning (Pradhan, 1998). Similarly, productivity, democratization, relevance and quality, professional power, and stability and change (Dalin, 1998).

Decentralization has a dramatic impact on the role of the head teacher. The traditional role has emphasized maintenance of administrative control, performance of bureaucratic routines. The emerging role may include multiple goals, a focus on facilitating change, and use of evaluation and professional sources of information, which vital for quality education.

One of the strong motivations for schools based decision making is that the ones who best understand the contexts and cultures of the schools, which is why it is important to give them real power and to enable them to become jointly responsible for student learning. At the same tine, education systems around the world have doubled and tripled enrolments. The increase in teachers and students forced, the capacity of centralized bureaucracies maintain quality is questionable? Increasing public dissatisfaction has resulted in pressures to shift decision making to local levels. Similarly, the emergence of new information and communication technologies has made it possible to achieve high levels of control over systems, with decentralized management. A new paradigm of management emphasizing attention to outputs rather than inputs gave increased important to strengthening local capacity for decision making.

\section{Educational decentralization practice in nepalese context}

The policy initiatives towards decentralization of education in Nepal were taken after the democracy. First, introduced a plan and scheme of decentralization of education in 1070s, the name of National Education system plan-2028-2032. The actual decentralized planning process was initiated in the 1990s, with implementation externally and internally funded Basic and Primary Education Project I (BPEP-I) and Basic and Primary Education Programme-II (BPEP-II). Similarly, implemented Secondary education perspective plan-1997, Higher secondary perspective plan in 1998, Secondary education support programme in 2002 and School sector reform plan in 2009-2015.

The goverment is committed to a decentralization path in education. Nevertheless there are divergent views within it on whether this means merely deconcentration of the service delivery by ministries, or weather it means granting significant power and responsibilities to local governments to run the local services. It has already been noted that the local self Governance Act and $7^{\text {th }}$ amendment to the education act are not in alignment, and that discussions are already under way as to reconciling these different approaches. The programme is based on the assumption that it supports active decentralization of education services delivery to local government level and that the DEOs will have to work increasingly closely with DDCs and VDCs (DANIDA,ADB \& HMG Nepal,2002). While implementing these plan and programs, the required institutions and management structures at central and local levels to carry out activities.

Generally speaking, although decentralization policies are closely linked to the specific country context, they are underpinned by three main motives. First, they aim to increase the effectiveness of education making it more relevant to local needs. Second, they 
are a means of democratically promoting people's participation by empowering to local authorities. Third, by putting emphasis on performance accountability they intend to improve service provision.

A review of current practice shows four broad application models: First, cascading office model which consists of local level units of the central office with varying degrees of authority but under the control of the ministry. Second, local self government model: locally elected bodies which function as a part of democratic framework and whose powers are defined by law, such as, the local self governance act and the education act \& regulation. Third, semi autonomous local unit. Autonomous structures created at the local level to implement education development programmes often as an efficient means of transferring resources and establishing accountability for large projects. Four, Bipolar model. School based management reforms which keep only two layers, the central and the school, while dismantling practically all intermediary layers of management (UNESCO,2003:5-6). Decentralization in most developing countries is interpreted in three complementary way: asking elected local authorities to take charge of education in their area. Second, strengthening the role of regional and district education offices, and third, increasing school autonomy in resources management (UNESCO,2004:5).

Attempts were made to ensure participation of the stakeholders and communities in planning and monitoring process. It may be noted that these institutional and other administrative reforms have not part of the mainstreams educational reform, and therefore, it has very difficult to sustain them beyond the plan period. As a result, the outcomes of such efforts to decentralize educational planning at the local level have not encouraging.

\section{Issues and problems of decentralization}

When the educational planning and administrations are entrusted to an autonomous body, the following issues and problems may be encountered : structure of decentralization: utilization of an already existing corporate body, or the establishment of a new corporate body, scope of the decentralization, professional competence of decentralized bodies, personnel polices, the administration of educational institution, the finance of education, the curriculum, and certification and examination, all are the major issues and problems, in educational decentralization (pradhan, 1998).

The research conducted by international institute for educational planning (IIEP) in many developing countries (sengal, mali, Guinea etc) on the implementation of decentralization mainly consisted of field studies on local education offices and schools. Several obstacles to the successful implementation of such a policy are: first, poor quality monitoring: one of the problems identified during the IIEP's research on decentralization policies in west Africa was poor quality monitoring on the part of the local education office, owing to the inadequacy of the financial, material and human resources at their disposal. Second, overloaded and under sourced schools: school principal also suffer from a work overload. The rise in the number of students entails a similar increase in the teaching force, and most of the new teaching staff are community or contract teachers who need regular supervision. Principals also have more extensive administrative duties. Third, lack of transparency : the inadequacy of the resources allocated by the central level forces local education offices and schools to seek alternative source of funding, generally from the parents. The director of the local office and the school principal have more autonomy as regard both the collection and use of such funds. The case studies revealed that they manage these funds entirely on 
their own. Fourth, different categories of teachers : there is a notable increase in the number of community, volunteer or contract teachers. Local authorities, school principals and communities recruit these teachers and, in most cases, pay their salaries. Fifth, little support: generally little support to the schools by the central governments (UNESCO,IIEP,2004:4-5).

It is argued that centralization promotes control, while decentralization fosters legitimacy. Often the central governments are concerned about maintaining effective control over implementation of education reform programmes, and at the same time, advocates decentralization to legitimize educational governance.

There are at least five main unresolved tension: first, who decides and controls decision making?. Second, the appointment and posting of personnel in general, to teacher in particular. Third, there is the issue of capacity building. Fourth, issue relates to information flow management. Finally, there are the financial arrangements and the three main ways of financing in decentralized contexts, namely through block grants from a guaranteed share of notional policy revenue, funds earmarked for specific programmes and incentive or matching funds that respond to local proposals (UNESCO,2003:5-6).

\section{Conclusion}

Decentralization is one of the most important phenomena to affected educational planning and management. It has become reality in many countries. Decentralization more than delegation. Developing countries in which the centre level is relinquishing significant authority, provincial (federal) and district level leadership are evolving in some areas of planning and management. Decentralization reflects a philosophy of planning and management. It requires careful selection of which decisions to push down into the organization structure and which to hold near the top, specific policy making to guide the decision making, proper selection and training of people and adequate controls. In planning and organizing educational change, provincial and local education authorities may need to cope with a social and political power, completing interests among stakeholders, and patterns of social division that inhibit consensus based decision making.

Finally, the analysis of centralization and decentralization of educational planning and management suggest that proper mix or balance of various forms of decentralization will be important for quality education. It is hoped that this overview \& analysis of decentralization in educational planning will assist policy makers, planners, managers and various stakeholders to address the challenges in advancing education and furthering its contribution to all segments of society.

\section{References}

Aggrawal, J.C.(2008). Development and planning of modern education. Delhi: Vikas Publishing House.

Asian development bank (2001). Education and national development in asia. Manila: Author.

Cohen, J.M. and Peterson, S.B. (1999). Administrative decentralization: strategies for developing countries. USA: Kumarian press.

DANIDA, ADB and HMG (2002). Secondary education support programme. Kathmandu: Author.

Dalin,P.(1998). School development : theories and strategies. Newyork: Wellington House.

Florestal, K.and Cooper, R.(1997). Decentralization of education. Washington, D.C: The world bank.

Government of Nepal, MOE (2009). School sector reform plan 2009-2015. Kathmandu: Author.

Pradhan, R.M.(1998). Handbook of educational planning. Kathmandu: Central Department of Education. 
UNESCO (1989). Concerns and challenges in educational development. Bankok : Author.

UNESCO (1999). School based management. Paris: Author.

UNESCO (2004). Decentralization: can it improve school? News letter. XXII,4,1-5.

UNESCO (2008). Direction for education planning. News letter. XXVI,3,1-6.

UNESCO (2002). Learning through out life : chal- lenges for the twenty first century. Paris: Author.

UNESCO (2003). Decentralizing education: trends and issues. News letter. XXI,2,1-4.

Weihrich, H. and Koontz, H. (1994). Management : a global perspective. New Delhi: McGraw Hill.

Welsh, T. and McGinn, N.F. (1999). Decentralization of education: why, when, what, and how? Paris: UNESCO. 